\title{
Development Strategy of Subak for Supporting Agroecotourism Empowerment
}

\author{
Ketut Suamba \\ Departement of Agrobusiness \\ Faculty of Agriculture, Udayana University \\ Wayan Windia \\ Departement of Agrobusiness \\ Faculty of Agriculture, Udayana University \\ Sumiyati \\ Departement of Technical Agriculture \\ Faculty of Technological Agriculture, Udayana University \\ Wayan Tika \\ Departement of Technical Agriculture \\ Faculty of Technological Agriculture, Udayana University \\ Ni Nyoman Sulastri \\ Departement of Technical Agriculture \\ Faculty of Technological Agriculture, Udayana University
}

\begin{abstract}
Subak is a traditional irrigation system which has local knowledge society that has been inherited from generation to generation. Local knowledge in the form of sociocultural activities can be used as a strong binder in subak system. Local knowledge also can be used as agroecotourism empowerment. On the other hand, the development of Bali as one of the major tourist destinations in Indonesia, both positive and negative impacts. One of the negative impacts are reduced wetland phenomenon occurs due to land conversion. One way in conservation efforts is by making subak has a role in "Subak Development Strategy for Supporting Agroecotourism Empowerment". This requires the study objective of this study was (i) identify the strengths, weaknesses, opportunities, and threats in the SWOT analysis method to be able to develop agroecotourism empowerment, and (ii) formulate strategies needed by Subak in preparing developing utilization of agroecotourism empowerment. The study was conducted at the Subak Wangaya Betan, Penebel, Tabanan and Subak Lodtunduh, Ubud, Gianyar. The results of the analysis of internal and external factors after taking into account the weight and rating, at each subak sample resulted in a score for determining the development strategy of agroecotourism in subak system. In Subak Lodtunduh obtained internal factor is the total value of 47.5 and the value of the external factors is 20. At Wangaya Subak Betan obtained internal factor is the total value of $\mathbf{1 1 . 5}$ and the value of the external factors is 24 score of the final results of internal and external factors included in the diagram to obtain the location of the chosen strategy to develop agroecotourism in subak is concerned. In the results obtained Subak Lodtunduh, Subak development strategy on aggressive quadrant. Thereby also the Subak Betan Wangaya, Subak development strategy is obtained in aggressive quadrant. Thus the efforts needed to be more aggressive in the development of the agroecotourism subak system.
\end{abstract}

Keywords : subak, agroecotourism, SWOT 


\section{INTRODUCTION}

Subak as one of the world's cultural heritage, not just an institution in the field of agriculture, but also a part of the local Balinese wisdom about the relationship between man and God, human relationships, and the relationship between human and nature environment (concept of Tri Hita Karana). Furthermore Susanto, 1999 saw the indigenous people of Bali just about the relationship between humans and the natural environment. Subak has local knowledge society that has been inherited from generation to generation, among others, has the nature of socio-cultural and socio-religious unique and superior (Ginter, 2003).

As a socio-cultural system, Subak has weaknesses. Windia (2008) mentions that one of the weaknesses of the irrigation system that is based on socio-cultural, as well as subak, is difficult to resist interventions that come from external parties, such as the utilization of water resources and land. Subak system always weaker position than others who utilize these resources.

The island of Bali is still a major tourist destination in Indonesia. Along with the development of tourism, a phenomenon which occurs due to the reduction of rice fields because of land conversion. Land conversion that occurred in Bali is large enough that an average of 750 hectare/year (Sutawan, 2005; Lorenzen, 2010). This is part of the challenge or threat to the existence of subak which directly or indirectly caused by the development of tourism in Bali (Sutawan, 2005; Windia, 2011).

There is a tendency that in the future subak system needs to be developed into an organization-oriented economy in addition to perform functions principally as irrigation water management, without having to sacrifice socio-religious (Sutawan, 2005). One way is with the conservation efforts subak synergize with tourism. This requires the development of tourism activity on the subak system as an effort to empower and maintain the sustainability of the subak system in Bali. As a first step of the implementation of these efforts, the necessary "Subak Development Strategy for the Exploitation Support Agroekowisata".

The development of tourism in the subak system is expected as a sub activity of the subak system with economic activity. These activities can provide benefits which are: to preserve natural resources, conserve local technology, and increase the income of farmers/communities around tourist sites, so hopefully will be able to support the empowerment and safeguarding subak system in Bali.

\section{Objectives}

The objectives of this research was: (i) identify the strengths, weaknesses, opportunities, and threats by the method of SWOT analysis on the system to be able to develop cultivation subak agro ecotourism; (ii) formulate strategies needed by subak to enhance the knowledge, skills, and management of subak as the community development efforts of the subak system in preparation for developing agroecotourism exploitation; and (iii) formulate activities and facilities needed in order to improve the ability of income (income generating capacity) system in an effort to maintain continuity subak system.

\section{METHODOLOGY}

The research was conducted in Subak Wangaya Betan, Penebel, Tabanan and Subak Lodtunduh, Ubud, Gianyar. The population in this study are all stakeholders associated with the development of agriculture as well as tourism and culture, namely: (i) members of Subak, (ii) management of Subak, (iii) the Department of Tourism, (iv) the Department of Agriculture, 
(v) the Department of Culture, (vi) the travel agency, (vii) the local government, and (viii) the decision makers in the region concerned subak.

\section{Data Collection}

Data collection was carried out with various activities as follows.

a. Conducting interviews with respondents using a questionnaire that has been prepared, to determine the elements of the strengths, weaknesses, opportunities, and threats (SWOT). Furthermore formulated strategies to be undertaken by the subak in order to develop agroecotourism.

b. A meeting with members of the subak to gain a common agreement on the formulation of development strategies agroecotourism. This activity is carried out by the method of Rapid Rural Appraisal (RRA).

c. Conducting interviews with some key respondents were considered to have a broad knowledge in order to develop agroecotourism.

d. Do the search field to know clearly about the condition of the field at the sample subak.

\section{DATA ANALYSIS}

SWOT analysis is based on the logic that maximizes the strengths and opportunities, but simultaneously can minimize weaknesses and threats (Rangkuti, 2008). SWOT analysis is done in three stages, namely the collection of data (input stage), analysis (matcing stage), and decision-making (decision stage). In identifying subak, from data obtained through field survey. SWOT analysis is done to obtain alternatives subak development strategy in the rapid development of tourism in Bali.

Tools used to formulate strategic factors is the SWOT matrix. This matrix can clearly describe how external opportunities and threats faced can be tailored to the strengths and weaknesses. Formulation of strategies needed in order to develop the cultivation subak agroecotourism, conducted by Participatory Rural Appraisal (PRA). PRA is an approach in the process of empowerment and citizen participation, the emphasis on community involvement in the overall development activities.

\section{Overview Subak Lodtunduh}

\section{RESULTS}

Subak Lodtunduh area in Desa Singakerta area, District of Ubud, Gianyar. Ubud is a cultural tourism based area. Subak Lodtunduh is 25.67 hectare with a total membership of 75 people consisting of 56 landowners and 19 tenant farmers (share-croppers). Subak Lodtunduh is as follows.

North: Subak Gagalan

East: Subak Tebongkang

South: Subak Kalangan Samu

West: Subak Bija

Water source for farming activities derived from Kedewatan weirs on the Ayung River and flows into Subak Lodtunduh through Yeh Lauh River. Pasedahan named Pasedahan Yeh Lauh which is consist 33 Subak in Badung, Denpasar and Gianyar Regency.

In general, farmers in Subak Lodtunduh using 90\% of the average area of land is for rice commodity and $10 \%$ of the average area of land is for non-rice commodities such as kale, 
sweet potatoes, pacar flowers, and chili. Marketing of farm systems in Subak Lodtunduh generally done with slash system. But there are also farmers who direct market their crops to market, and some are selling half his crop and partly for consumption

\section{Overview Subak Wangaya Betan}

Subak Wangaya Betan is situated in Desa Mangesta, District Penebel, Tabanan Regency, Bali Province. Subak Wangaya Betan as follows:

North: the mountainous area bordering the Buleleng

East: Badung Regency

South: Ocean Indonesia

West: Jembrana

Subak Wangaya Betan is approximately 76 acres, the number of subak members 96 peoples, consisting of three munduk namely: (1) Munduk Juukan, (2) Munduk Desa, and (3) Munduk Manggis. Geographically, Subak Wangaya Betan are on higher ground on the slopes of Gunung Batukaru, Tabanan and entered as a buffer area of world cultural heritage Jatiluwih.

Cropping patterns in Subak Wangaya Betan apply cropping pattern known as kerta masa (performed simultaneously on a good day). Arrangements are usually made by consensus by members of Subak lead by pekaseh.

Subak Wangaya Betan's water source comes from springs in the region Wangaya Betan Hamlet, Village Mangesta. Implementation of water distribution is done by meeting or rules based tektekin or kecoran (water discharge). Ration irrigation water received by a member in Subak Wangaya Betan based on ayahan system (as compensation obligations of the right to water). Water rights received by a member of the subak will be accompanied by the obligation ngayah in any subak activity.

\section{SWOT analysis}

In conducting a SWOT analysis on subak samples, determined internal factors (strengths and weaknesses) and external factors (opportunities and threats). The elements in each of the internal and external factors grouped in mindset aspects, social aspects, and aspects of the artifacts or material.

After identification of the elements of the internal and external factors, further analysis matrix composed strategy by giving weighting to each element of the internal and external factors and rating of each element on the internal and external factors in accordance with the conditions of the subak samples. Total weight for the internal factor is $100 \%$ and then divided by average $50 \%$ each

for strengths and weaknesses. Similarly to external factors.

Rating of all the elements of strengths, weaknesses, opportunities and threats carried out with a value rating and category as shown in Table 3 . Results of the final score on the internal and external factors Subak Lodtunduh then substitution in the diagram to be able to obtain the location of the chosen strategy to develop agroecotourism in Subak Lodtunduh, as presented in Figure 3. 
Table 3: Category rating on the internal and external factors

\begin{tabular}{|c|c|c|c|}
\hline Rating & Catagory & Internal factors & Exsternal factors \\
\hline-5 & verry bad & Weakness & Threat \\
\hline-4 & Bad & Weakness & Threat \\
\hline-3 & almost bad & Weakness & Threat \\
\hline-2 & no bad & Weakness & Threat \\
\hline-1 & verry no bad & Weakness & Threat \\
\hline 1 & verry no good & Strength & Opportunity \\
\hline 2 & no good & Strength & Opportunity \\
\hline 3 & Good & Strength & Opportunity \\
\hline 4 & Best & Strength & Opportunity \\
\hline 5 & Better & Strength & Opportunity \\
\hline
\end{tabular}

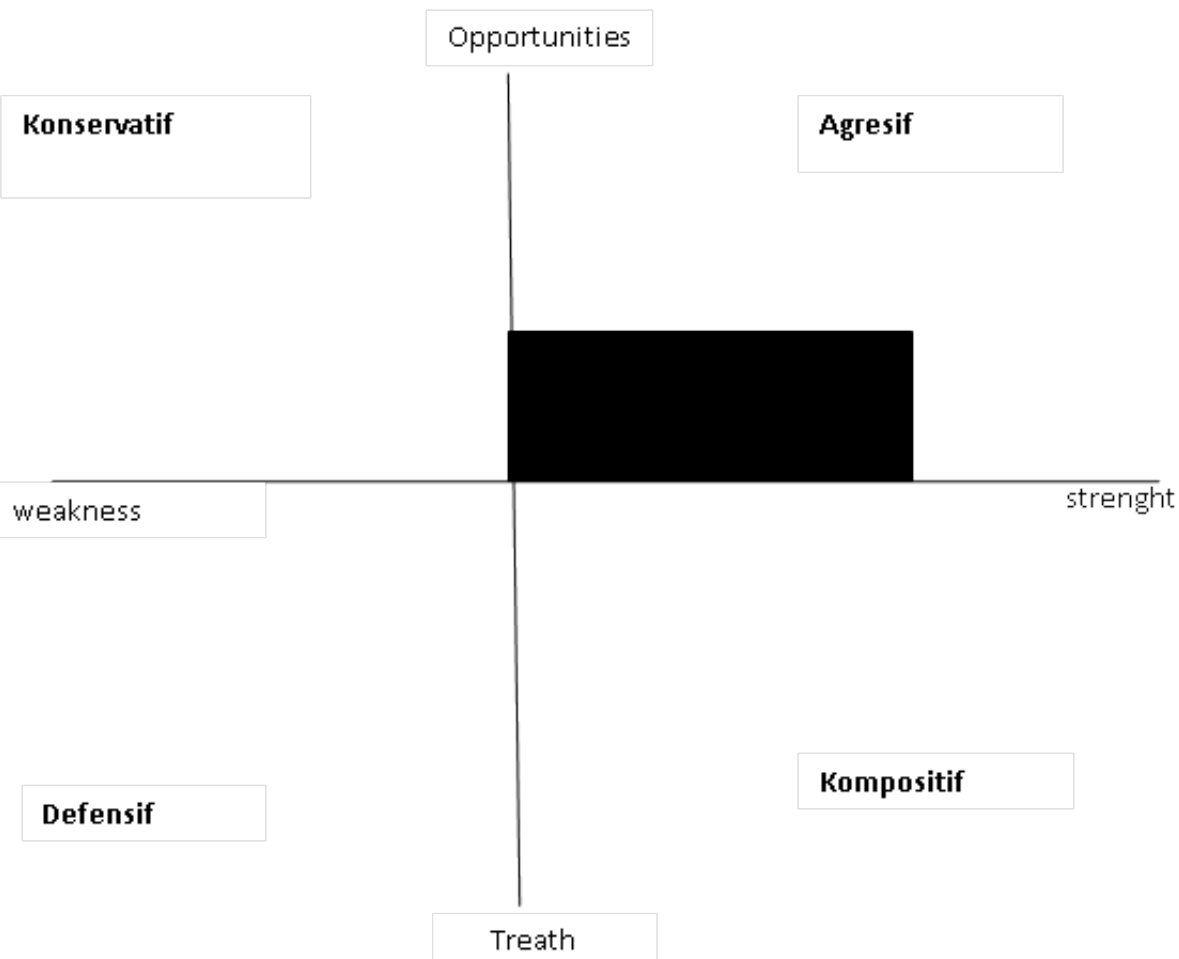

Fig 3. Subak Lodtunduh SWOT analysis Diagram

The results of the final score on the internal and external factors Subak Wangaya Betan then substitution in the diagram to be able to obtain the location of the chosen strategy to develop agroecotourism in Subak Wangaya Betan, as presented in Figure 4. 


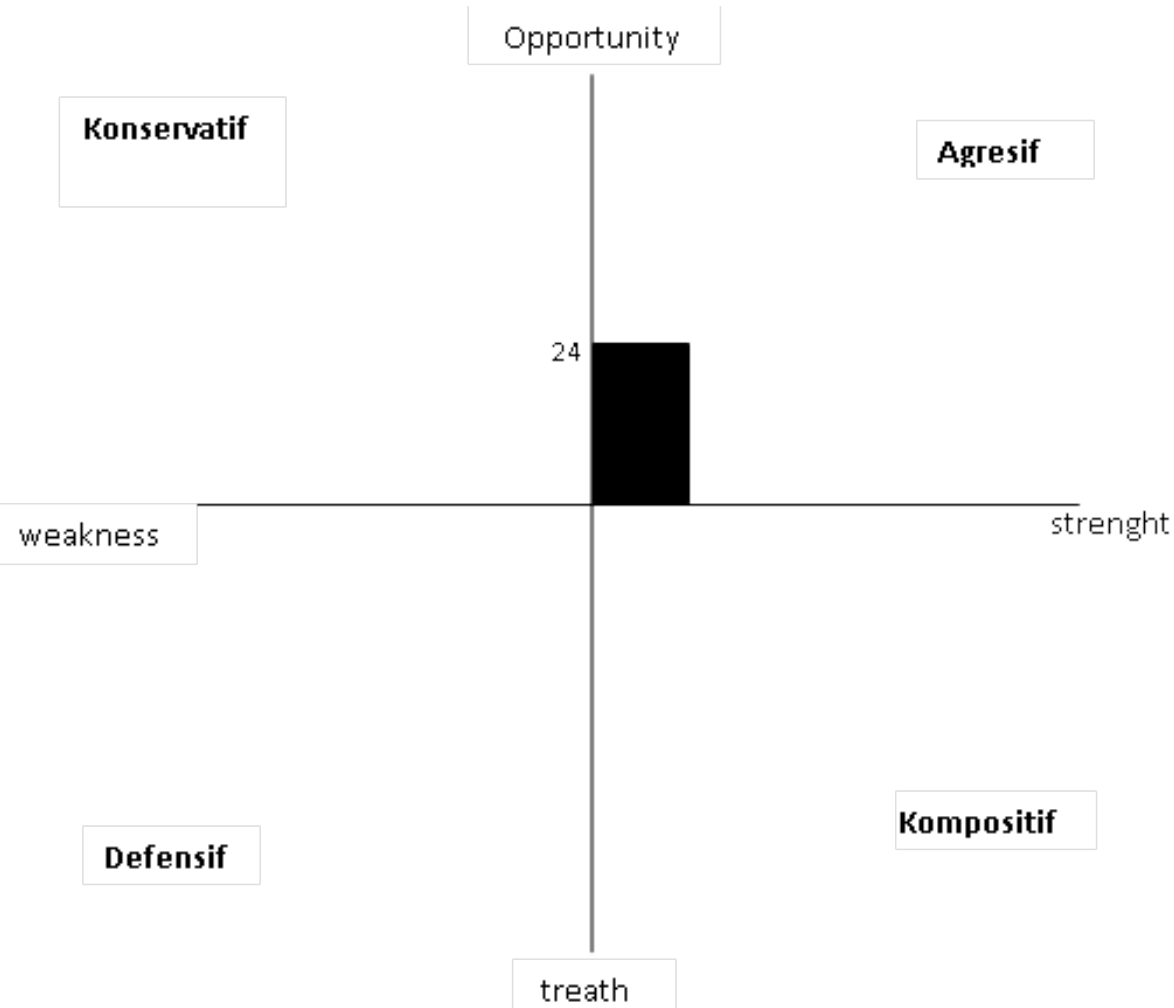

Fig 4. Subak Wangaye Betan SWOT Analysis diagram

\section{Development Strategy based on SWOT Analysis}

Based on the results obtained in the SWOT analysis diagram, it can be determined implementation strategy through activities that can be carried out in accordance with the SWOT analysis has been done for the corresponding water control system in order to prepare and support the operation of agroecotourism to be done.

\section{Development Strategy on Subak Lodtunduh}

Strategies that can be implemented according to the SWOT analysis has been done for Subak Lodtunduh to prepare and support the operation of agroecotourism to be done, can be the following activities.

a. The formation of sub-managers of agroecotourism businesses under institutional subak

b. Adjacent to the increase in value-added products

c. Repair some infrastructure, namely: the improvement of some point on the path tracking, improved support facilities (toilets, etc.), procurement / repair restoration, repair stop over

d. Assistance in improvement plan tracking path

e. Assistance in promotion through various media (brochures, web, etc.)

f. Technology assistance in making souvenirs include: production, packaging, presentation, and marketing

g. Assistance for mediation to local governments and related agencies, namely: Local Government, Department of Tourism, Department of Culture, Department of Agriculture and Foodstuffs, and Travel Agents

h. Assistance in mastery of information technology upgrades

i. Assistance in strengthening awig awig for control over the land. 


\section{Development Strategy on Subak Wangaya Betan}

Strategies that can be implemented according to the SWOT analysis has been done for Subak Wangaya Betan to prepare and support the operation of agroecotourism to be done, can be the following activities.

a. The formation of sub-managers of agroecotourism businesses under institutional subak

b. Adjacent to the increase in value-added products

c. Repair some infrastructure, namely: improved access road to the site, repair some point on the path tracking, improved support facilities (toilets, etc.), procurement / repair restoration, and repair stop over

d. Assistance in manufacture of floor plan tracking path

e. Assistance in promotion through various media (brochures, web, etc.)

f. Technology assistance in making souvenirs include: production, packaging, presentation, and marketing.

g. Assistance for mediation to local governments and related agencies, namely: Local Government, Department of Tourism, Department of Culture, Department of Agriculture and Foodstuffs, and Travel Agents.

h. Assistance in mastery of information technology upgrades

i. Assistance in strengthening awig awig for control over the land.

\section{CONCLUSION}

Based on the SWOT analysis for Exploitation Agroecotourism For Effort Community Development and Capacity-Building Revenue (Income Generating Capacity) at subak samples, obtained the location of the chosen strategy to develop agroecotourism on Subak Lodtunduh is an aggressive strategy. Similarly, the location of the strategy chosen to develop the Subak Wangaya Betan agroecotourism is an aggressive strategy.

Strategies that can be implemented according to the SWOT analysis has been done for Subak Lodtunduh to prepare and support the operation of ecotourism to be executed, may be the activities: the establishment of sub-managers of agroecowisata businesses under subak institutions, assistance to the increase in value-added products, the improvement of some infrastructure, mentoring improvement plan tracking path, promotion assistance through a variety of media, technology assistance in the manufacture of souvenirs, for mediation assistance to local governments and related agencies, assisting mastery of information technology capacity building, and strengthening mentoring awig awig for control over the land.

To Subak Wangaya Betan strategies to prepare for and support the operation of ecotourism to be executed, may be the activities: the establishment of sub-managers of businesses agroecotourism under subak institutions, assistance to increase the added value of products, repair some infrastructure, assistance tracking path plan-making, promotion assistance through a variety of media, technology assistance in the manufacture of souvenirs, for mediation assistance to local governments and related agencies, assisting mastery of information technology capacity building, and strengthening mentoring awig awig for control over the land.

\section{References}

Ardana, I Gusti Gde; I Wayan Ardika; I Ketut Setiawan.2012. Raja Udayana di Bali, Udayana Univ.Press, Denpasar.

Ginting, C.M. 2003. Melestarikan Subak Sebagai Obyek Wisata.

http://www.sinarharapam.co.id/berita/0804/03/kesra06.html (di download pada Desember 2008).

Lansing, J. Stephen. 2006. Perfect order recognizing complexity in Bali, Princeton Univ.Press, Princeton and Oxford. 
Lorenzen, R.P. and S. Lorenzen. 2010. Changing Realities-Perspectives on Balinese Rice Cultivation. Springer Science+Business Media, LLC. Hum Ecol (2011) 39:29-42. Published online : 17 August 2010.

http://ezproxy.ugm.ac.id:2052/content/j21000p58jh0p017/fulltext.pdf (di download pada 26 Juli 2011).

Purwita, Ida Bagus Putu. 1993. Kajian sejarah subak di Bali, dalam Subak, sistem irigasi tradisional di Bali (ed: I Gde Pitana), Upada Sastra, Denpasar.

Rangkuti, F. 2008. Analisis SWOT : Teknik Membedah Kasus Bisnis. Penerbit PT. Gramedia Pustaka Utama. Jakarta.

Suteja, Wayan Mertha.2006. Dharmayana, leluhur kepurwa bumi kamulan-Amerika, Paramita, Surabaya,

Susanto, Sahid., 1999. A Study of the Subak as Indigenous Cultural, Social, and Technological System, to Establish a Culturally based Integrated Water Resources Management Vol. II. (ed : Sahid Susanto). Faculty of Agricultural Technology, Gadjah Mada University. Yogyakarta.

Sutawan, Nyoman., 2005. Subak Menghadapi Tantangan Globalisasi (dalam Revitalisasi Subak Dalam Memasuki Era Globalisasi, editor : I Gde Pitana dan I Gede Setiawan AP.). Andi Ofset. Yogyakarta.

Sutawan, Nyoman., 2008. Organisasi dan Manajemen Subak di Bali. Pustaka Bali Post, Denpasar.

Windia, Wayan. 2008. Menuju Sistem Irigasi Subak yang Berkelanjutan di Bali. Pidato Pengukuhan Jabatan Guru Besar Dalam Bidang Ilmu Sosial Ekonomi Pertanian Pada Fakultas Pertanian Universitas Udayana. Denpasar.

Windia, Wayan, Made Wirartha, Ketut Suamba, dan Made Sarjana. 2008. Model Pengembangan Agrowisata di Bali. SOCA (Socio-economic of Agriculture and Agribusiness). Jurusan Sosek, Fakultas Pertanian, Universitas Udayana, Denpasar, Bali-Indonesia. http://ejournal.unud.ac.id/abstrak/(13)\%20soca-windia\%20dkk-agrowisata(1).pdf 